\title{
Ceruloplasmin and iron in Alzheimer's disease and Parkinson's disease: a synopsis of recent studies
}

This article was published in the following Dove Press journal:

Neuropsychiatric Disease and Treatment

I November 2012

Number of times this article has been viewed

\author{
Jakob Kristinsson' \\ Jón Snaedal² \\ Gudlaug Tórsdóttir ${ }^{1,2}$ \\ Torkell Jóhannesson' \\ 'Department of Pharmacology and \\ Toxicology, University of Iceland, \\ Reykjavik, Iceland; 'Department of \\ Geriatrics, Landspitali University \\ Hospital, Reykjavik, Iceland
}

\begin{abstract}
Ceruloplasmin (Cp) concentration and oxidative activity in serum are lowered in Parkinson's disease (PD). In most PD patients, iron increases in the substantia nigra in the midbrain. In $\mathrm{PD}$, the low $\mathrm{Cp}$ concentration and activity in serum and the high iron amounts in the substantia nigra appears to be correlated. An hereditary background is common in PD and variations in the $\mathrm{Cp}$ gene that have been found in PD are associated with high iron levels in the substantia nigra. Variations in $\mathrm{Cp}$ synthesis and in the incorporation of copper into the $\mathrm{Cp}$ molecule are essential features of PD. In Alzheimer's disease (AD), the Cp activity in serum is lowered but not the concentration, except in the advanced stages of the disease. Generally, iron is not increased in the $\mathrm{AD}$ brain. In the $\mathrm{AD}$ brain, iron accumulates in neuritic plaques and in neurofibrillary tangles. There is also increased risk of iron-mediated tissue damage, which may possibly be counteracted by $\mathrm{Cp}$. At the same time, the AD brain is short in copper, which presumably results in the deficient activity of many copper enzymes in the brain, in addition to $\mathrm{Cp}$. Lowered $\mathrm{Cp}$ activity in serum most likely stems from lessened incorporation of copper in the $\mathrm{Cp}$ molecule and similar incorporation defects might also apply to other copper enzymes in $\mathrm{AD}$.
\end{abstract}

Keywords: ceruloplasmin, iron, copper, Alzheimer's disease, Parkinson's disease

\section{Introduction}

The role of the oxidative (ferroxidase) activity of the multi-copper enzyme ceruloplasmin (Cp) in iron homeostasis was first described around $1970 .{ }^{1}$ Later experiments in mice with disruption of the $\mathrm{Cp}$ gene (located on chromosome 3 ) showed that $\mathrm{Cp}$ is essential in moving iron out of the reticuloendothelial cells and hepatocytes. ${ }^{2}$ It was subsequently found that $\mathrm{Cp}$ exists not only in a free, secreted form but also in a bound, glycosylphosphatidylinositol (GPI)-anchored form in astrocytes in the central nervous system (CNS). These experiments concluded that GPI-Cp is required for the cellular efflux of iron in the CNS and that defects in this activity might lead to the accumulation of iron in the brain and result in neurodegenerative lesions. ${ }^{3}$ Aceruloplasminemia is a rare autosomal, recessive disorder in which ceruloplasmin is, as the name indicates, missing in serum and in other tissues. In line with this, aceruloplasminemia is characterized by impaired iron homeostasis with iron deposits in the brain and other organs. ${ }^{4,5}$ There is considerable evidence that connects Alzheimer's disease (AD) with disturbed iron homeostasis in the brain. Thus, alterations have been found in the normal cellular distribution of iron and iron proteins in the AD brain ${ }^{6}$ and it is hypothesized that the aberrant distribution of iron in the AD brain could lead to oxidative damage. ${ }^{7}$ Also, many hereditary causes of disrupted iron homeostasis, including aceruloplasminemia,
Correspondence: Jón Snaedal

Memory Clinic, Geriatric Department Landspitali, University Hospital,

IS I0I, Reykjavik, Iceland

Tel +3548640478

Email jsnaedal@landspitali.is 
result in iron depositions in the brain and movement disorders that are reminiscent, at least partially, of Parkinson's disease (PD) (reviewed by Ponka ${ }^{8}$ ). In PD patients specifically, a negative correlation has been found between the $\mathrm{Cp}$ concentration and the oxidative activity in serum and iron deposits in the substantia nigra in the brain. ${ }^{9,10}$

The gene for apoceruloplasmin is, as mentioned above, located on chromosome 3 near the gene areas for transferrin and transferrin receptors. ${ }^{11}$ The gene for the ATPase (ATP7B) that is responsible for the incorporation of copper into fully developed holoceruloplasmin is located on chromosome $13 .{ }^{12}$ Thus, disorders of these two synthetic processes obviously have different causes. In the authors' studies, care was taken to determine both $\mathrm{Cp}$ parameters in order to elucidate what role Cp activity might play, specifically in these diseases. ${ }^{13-16}$ The data from the two AD studies and the two PD studies of the authors are shown in Table 1.

In this short presentation, based on recent studies, the authors elaborate the contention that defective $\mathrm{Cp}$ mechanisms, which are evident in the serum of AD and PD patients, may relate to the etiology of these diseases, although they may manifest themselves in iron disorders of the CNS. However, a note of caution should be added in this context; in the living patient, there is no way of knowing whether alterations in $\mathrm{Cp}$ parameters in serum correspond to similar changes in $\mathrm{Cp}$ in the brain.

\section{Ceruloplasmin in serum and iron in Parkinson's disease}

PD is primarily a disjunction of dopaminergic neurons located in the substantia nigra in the midbrain and neurons in the basal ganglia, collectively named the extrapyramidal brain region. More iron is found in this region than in any other region in the brain. In PD, the dopaminergic neurons of substantia nigra degenerate and lose their blackish color, and the iron content usually increases further. Inside many of the degenerated neurons are amyloid formations, so-called Lewy bodies, which bind iron. Lewy bodies consist of many substances. In the core of the Lewy body is a protein, $\alpha$-synnuclein, of uncertain biological function, and iron seems to be a requisite for its deposition and accumulation. In PD, there is also a loss of ferritin in the neurons of the midbrain. ${ }^{17-19}$ Thus, in PD, iron might be deposited in a disorderly manner in extrapyramidal structures, resulting in tissue damage, as is the case with neuromelanin, as discussed later.

In the authors' study on 40 PD patients, the results showed that both the $\mathrm{Cp}$ concentration and oxidative activity in serum were significantly lower than in the age- and sex-matched healthy controls. ${ }^{13}$ Five years later, 28 of the patients were still alive and consented to further study. At that point, they were the same age as the original group but had progressed further in the disease. Results from the latter study were identical to the first study. ${ }^{14} \mathrm{Cp}$-specific activity (oxidative

Table I Cp concentration, oxidative activity, and CP-specific oxidative activity in two studies of PD patients and two studies of AD patients compared to healthy and age- and sex-matched controls

\begin{tabular}{|c|c|c|c|c|}
\hline Determinations & $\begin{array}{l}\text { Patients, } \\
\text { mean (range) }\end{array}$ & $\begin{array}{l}\text { Controls, } \\
\text { mean (range) }\end{array}$ & $\begin{array}{l}\text { Number } \\
\text { of pairs }\end{array}$ & $P$-values \\
\hline \multicolumn{5}{|l|}{ PD patients (study I) ${ }^{13}$} \\
\hline Ceruloplasmin concentration, $\mathrm{mg} / \mathrm{mL}$ (serum) & $342(160-560)$ & $388(180-600)$ & 40 & $0.0006^{\mathrm{a}}$ \\
\hline Ceruloplasmin oxidative activity, units/mL (serum) & $110(60-193)$ & $139(65-222)$ & 40 & $0.0006^{\mathrm{a}}$ \\
\hline Ceruloplasmin specific oxidative activity, units/mg (serum) & $322(195-515)$ & $362(202-544)$ & 40 & $0.0094^{\mathrm{a}}$ \\
\hline \multicolumn{5}{|l|}{ PD patients (study 2; follow-up study) ${ }^{14}$} \\
\hline Ceruloplasmin concentration, $\mathrm{mg} / \mathrm{mL}$ (serum) & $284(210-390)$ & $316(240-460)$ & 28 & $0.0067^{\mathrm{b}}$ \\
\hline Ceruloplasmin oxidative activity, units/mL (serum) & $94(42-176)$ & $125(52-236)$ & 28 & $0.0024^{\mathrm{b}}$ \\
\hline Ceruloplasmin specific oxidative activity, units/mg (serum) & $325(|73-5| 8)$ & $377(217-544)$ & 24 & $0.029 I^{b}$ \\
\hline \multicolumn{5}{|l|}{ AD patients (study $I)^{15}$} \\
\hline Ceruloplasmin concentration, $\mathrm{mg} / \mathrm{mL}$ (serum) & $382(247-562)$ & $383(222-655)$ & 44 & $>0.05^{a}$ \\
\hline Cp oxidative activity, units/mL (serum) & $89(47-155)$ & $136(79-227)$ & 26 & $0.0005^{\mathrm{a}}$ \\
\hline Cp specific oxidative activity, units/mg (serum) & $219(144-322)$ & $338(255-442)$ & 26 & $0.000 I^{\mathrm{a}}$ \\
\hline \multicolumn{5}{|l|}{ AD patients (study 2$)^{16}$} \\
\hline Ceruloplasmin concentration, $\mathrm{mg} / \mathrm{mL}$ (serum) & $225(100-400)$ & $220(150-340)$ & 40 & $>0.05^{c}$ \\
\hline Cp oxidative activity, units/mL (serum) & $119(68-201)$ & $136(69-179)$ & 41 & $0.0165^{c}$ \\
\hline Cp specific oxidative activity, units/mg (serum) & $568(283-1093)$ & $611(345-814)$ & 40 & $0.0040^{c}$ \\
\hline
\end{tabular}

Notes: The mean values and the range of the individual results and the $P$-values relevant to comparison of the patient and the control groups are shown. PD study 2 was a follow-up study of the 28 patients living (out of 40) 5 years after participating in PD study I and their healthy controls. AD study I and AD study 2 were independent studies 12 years apart. In the AD studies, the values for $C_{p}$-specific oxidative activity are not comparable between the two rounds. This is due to methodological changes in the determination of Cp concentration in serum. "Wilcoxon's matched pairs test; 'Student's $t$-test; 'Mann-Whitney test.

Abbreviations: AD, Alzheimer's disease; Cp, ceruloplasmin; PD, Parkinson's disease. 
activity related to mass) was calculated. In both studies, the $\mathrm{Cp}$-specific activity was significantly lower in the patients than in the controls. Thus, the quality of the enzyme must have been significantly deteriorated in the patients and this can best be explained by lowered incorporation of copper into the Cp molecule ${ }^{13,14}$ (see also Table 1).

$\mathrm{Cp}$ is a so-called acute phase reactant. Accordingly, serum concentration increases during various conditions associated with oxidative stress. In these circumstances, the acute increase of $\mathrm{Cp}$ concentration is generally ascribed to increased transcription of the $\mathrm{Cp}$ gene by cytokines, especially interleukin-6. ${ }^{11}$ In healthy persons, increased $\mathrm{Cp}$ concentration may be matched by increased special activity in serum, as is the case in advanced age. ${ }^{20}$ In disease, increased $\mathrm{Cp}$ concentration may, on the other hand, represent a compensatory mechanism for pathologically low Cp oxidative activity. ${ }^{21,22}$ In the opinion of the authors, this may have been the case in Arnal et al. ${ }^{23}$ These authors found that the $\mathrm{Cp}$ concentration increases with the deterioration of disease in PD patients and, at the same time, observed an increase of the free copper (not bound to $\mathrm{Cp}$ ) in serum. The increase in free copper is indicative of a lower incorporation of copper into the $\mathrm{Cp}$ molecule and, consequently, the lower $\mathrm{Cp}$ activity was compensated by increased $\mathrm{Cp}$ concentration.

Two recent studies have dealt with the relation between $\mathrm{Cp}$ parameters in serum and iron in the substantia nigra. In the first study, by Jin et al, ${ }^{9}$ iron was determined by magnetic resonance in seven brain regions in PD patients. Iron was significantly increased in the substantia nigra of these patients only if they also had low $\mathrm{Cp}$ concentration in serum. In PD patients with normal $\mathrm{Cp}$, concentration in serum iron was not increased in the substantia nigra, nor was increased iron found in other brain regions. Thus, it was concluded from this study, that at least two variants of PD might exist: (1) PD with high iron in the substantia nigra and low $\mathrm{Cp}$ concentration in serum, and (2) PD with normal iron in the substantia nigra and normal $\mathrm{Cp}$ concentration in serum. In the second study, by Martinez-Hernandez et al, ${ }^{10} \mathrm{Cp}$ oxidative activity in serum was negatively correlated with the iron content of the substantia nigra. In this study, increased iron was found in the substantia nigra of all patients and the Hoehn and Yahr scores were, on average, about the same (2.45 and 2.40, respectively) as in the first PD study of the authors. ${ }^{13}$

In another study, iron was found in pathologically high amounts in the substantia nigra of more than $90 \%$ of all the PD patients studied. Large amounts of iron were also found in the substantia nigra of close relatives of the PD patients, although only a few of them had manifest symptoms of the disease. Moreover, iron was found in large amounts in the substantia nigra of a relatively small number of healthy persons unrelated to the $\mathrm{PD}$ patients. ${ }^{24}$ Thus, the accumulation of iron in the substantia nigra, although common in PD, is seemingly not enough in itself to produce the clinical symptoms of PD. Extensive research should be instituted in this field and especially with a view to detecting possible defects in $\mathrm{Cp}$ synthesis. In this context, it is of interest that $\mathrm{Cp}$ gene variations have been associated with iron accumulation in the substantia nigra in PD patients. ${ }^{25}$

The oxidative activity of ceruloplasmin is seemingly involved in the oxidation and polymerization of redundant catecholamines (dopamine, norepinephrine, epinephrine) in neurons where these amines function as transmitter substances. ${ }^{26}$ A common name for these polymerization products is neuromelanin. It binds iron and impacts the blackish-blue color on catecholaminergic neurons in the substantia nigra and locus coerulus in the midbrain and pons. By binding iron, neuromelanin obviously has a regulatory function in keeping the levels of noxious ferrous iron $\left(\mathrm{Fe}^{2+}\right)$ low in these iron-rich structures. In PD, degenerative or dying neurons release neuromelanin (and deplete their color), which is digested by microglia. The iron released from neuromelanin could subsequently lead to iron-mediated tissue damage. ${ }^{27}$ Thus, it is reasonable to assume that high $\mathrm{Cp}$ oxidative activity might counteract this process and obviate the occurrence of PD.

Rotenone is an organic substance found in plants (Derris root and some other tropical and subtropical plants). It is one of several substances that, in experiments with rats and mice, was found to induce a condition that could be used as a model of PD. Among these substances, rotenone has been found to have the most specific effect on dopaminergic neurons. ${ }^{28}$ Rotenone is an inhibitor of NADH dehydrogenase in the mitochondria (complex I), which oxidizes NADH to NAD. Blocking this enzyme results in deranged electronic transport with lowered energy production and increased risks of developing noxious oxygen radicals. Dopaminergic neurons are especially sensitive to blocking of mitochondrial dehydrogenases. ${ }^{28,29}$

Two things are of special interest in animal studies with rotenone: first, rats and mice differ to a high degree in their sensitivity to the effect of rotenone; second, in mice at least, the difference in sensitivity to rotenone might refer to the levels of $\mathrm{Cp}$ in the animals. ${ }^{28-30}$

In summary, in $\mathrm{PD}$, lowered $\mathrm{Cp}$ concentration and oxidative activity in serum and increased iron in the substantia nigra are often concomitant occurrences. Deranged electronic transport and energy production in the mitochondria of nigral 
dopaminergic neurons may be an important cause of PD, with $\mathrm{Cp}$ possibly counteracting the process.

\section{Ceruloplasmin in serum and iron in Alzheimer's disease}

$\mathrm{AD}$ is the most common of the so-called dementias that result from the degeneration and death of cortical neurons in the brain. Prominent among the neurons that are affected early in $\mathrm{AD}$ are cholinergic neurons projecting to the hippocampus and hippocampal regions located in the temporal lobe. The pathological status in the AD brain is characterized by intracellular neurofibrillary tangles and intercellular neuritic plaques primarily located near synapses between neurons in the affected regions. Neurofibrillary tangles are considered to have more prospective value than the neuritic plaques in assessing the progress of the disease. ${ }^{18,31}$

Tau is a neuronal, microtubule-associated protein, the physiological function of which is to regulate microtubule dynamics. ${ }^{32}$ In $\mathrm{AD}$, the tau protein is phosphorylated to a pathological degree, leading to distortion of the microtubuli and splitting of the axonal structures. This results in the formation of neurofibrillary tangles. ${ }^{18,31}$ Thus, deficient axonal transport may be the real hallmark of the disease. In this context, it is interesting that oligodendrocytes, which are responsible for the synthesis of the myelin sheath, contain more iron than any other cells in the CNS, and they are also considered to put forward most of the transferrin in the brain. . $^{17,19,33,34}$

Amyloid precursor protein (APP) is a glycosylated protein of unknown biological function that is uniformly found in the membranes of cells in the body, but most abundantly in the brain. The protein is cleaved into several peptides by the following three intracellular enzymes: $\alpha$-, $\beta$-, and $\gamma$-secretases. In the CNS, these cleavage products might possibly have some regenerating or protecting effect on the integrity of synaptic structures. Most of the cleavage products are soluble and never accumulate or are found in tissue deposits. In AD, however, a less soluble variant, a $\beta$-peptide with 42 amino acids, is more prevalent. This $\beta$-peptide constitutes the amyloid core in the neuritic plaques. It is usually called $\mathrm{A} \beta$ and comprises the essential part of the plaques. ${ }^{18,31,35}$

Iron, along with copper and zinc (released during neural transmission), accumulates in the plaques and is, with or without the other metals, a requisite for the disposition of $\mathrm{A} \beta$ in the plaques. ${ }^{18}$ Iron binding to the hyperphosphorylated tau protein is also a precursory pattern to the formation of the neurofibrillary tangles. ${ }^{18}$ Thus, the two most prominent pathological features of the $\mathrm{AD}$ brain, plaques and tangles, are dependent on the presence of iron. ${ }^{17,19}$

Occurrence of the deleterious Fenton reaction, which is dependent on free $\mathrm{Fe}^{2+}$, is often observed in the early stages of $\mathrm{AD}$ or at the prodromal stage of the disease (mild cognitive impairment). The iron-mediated noxious oxidative activity in the $\mathrm{AD}$ brain is also negatively related to the occurrence of the neuritic plaques. ${ }^{36,37}$ This is in line with the fact that the plaques do not form without iron and, accordingly, may have a protective effect in mopping up wayward iron in the brain of AD patients. As the iron content in the AD brain is, in general, not increased, ${ }^{38}$ the abnormal iron accumulation in neurofibrillary tangles and neuritic plaques must be evidence of a dysfunctional status of iron in the brain. On the same line, Quintana et $\mathrm{al}^{39}$ hypothesize that, in $\mathrm{AD}$, dysfunctional ferritin (representing storage iron) may increase oxidative stress due to iron and myelin breakdown, which is also seen in old age. In this context, it is of interest that experiments with genetically engineered mice indicate that $\mathrm{Cp}$ plays an important role in protecting the CNS from iron-mediated free radical injury. ${ }^{40}$

The authors determined the $\mathrm{Cp}$ concentration and oxidative activity in the serum of 44 and $26 \mathrm{AD}$ patients, respectively, and in their age- and sex-matched controls. These patients had relatively mild disease (mean MMSE score 15.9). The $\mathrm{Cp}$ concentration was the same in both the patient and the control groups, but the $\mathrm{Cp}$ activity was significantly lower in the patient group. ${ }^{15} \mathrm{~A}$ second study of the same design was performed 12 years later on $40 \mathrm{AD}$ patients with mild disease (mean MMSE score 17.9) and their healthy controls. The results of this study were the same as in the first study ${ }^{16}$ (see also Table 1). Taken together, the uniform results of the two studies indicate that the Cp activity in serum, but not the Cp concentration, is lowered in AD. At any rate, this applies to the mild stages of $\mathrm{AD}$ and can best be explained by decreased incorporation of copper in the Cp molecule, while the synthesis of apoceruloplasmin is the same in both patients and controls.

Brewer et $\mathrm{al}^{41}$ determined $\mathrm{Cp}$ concentration and activity in the serum of $31 \mathrm{AD}$ patients with generally mild disease (mean MMSE score about 21.5) and their controls. In their studies, like the present authors' study, they found that the $\mathrm{Cp}$ activity was lowered in the patients but not the $\mathrm{Cp}$ concentration. At the same time, free copper in plasma (not bound to $\mathrm{Cp}$ ) was significantly increased in the patients. Brewer et al explained this by a lower degree of copper incorporation into the $\mathrm{Cp}$ molecule: "it lacks at least some of its coppers." 
Arnal et $\mathrm{al}^{23}$ determined $\mathrm{Cp}$ concentration in serum of $\mathrm{AD}$ patients on three different stages of the disease (from very mild to a severe stage; mean MMSE scores 11.622.2). In the most affected patients, the Cp concentration was significantly lower than in their controls but not in the two groups of patients that were less affected. Therefore, the possibility exists that the $\mathrm{Cp}$ concentration in serum may also be lower in the $\mathrm{AD}$ patients who were more heavily affected than in the study of Brewer et al ${ }^{41}$ or in the studies of the present authors. ${ }^{15,16}$ Arnal et a ${ }^{23}$ also found that free copper (not bound to $\mathrm{Cp}$ ) in plasma increased in the patients and was negatively correlated with the MMSE score.

In experiments with an animal model (rabbits) of $\mathrm{AD}$, Sparks and Schreurs found that trace amounts of copper in the drinking water of the animals accelerated AD's pathological changes in their brains and induced learning deficits in the animals. ${ }^{42}$ Subsequently, Squitti et al ${ }^{43-45}$ have argued that the level of free copper in plasma of AD patients is a predictive value in assessing the progression of the disease. The present authors are not aware that Squitti et al have, in their studies, also determined the $\mathrm{Cp}$ oxidative activity in serum along with the $\mathrm{Cp}$ concentration. It is, therefore, difficult to estimate whether the free copper in plasma in their studies was independent of changes in the $\mathrm{Cp}$ activity. From the study of Brewer et al, ${ }^{41}$ it can be concluded that an increase of free copper in plasma and decreased $\mathrm{Cp}$ activity in the serum of AD patients are interrelated phenomena. Moreover, copper has been found to be significantly lowered in the brain of AD patients. ${ }^{38}$ Until these differences have been sorted out, there seems little ground for instituting zinc therapy in $\mathrm{AD}$ patients in order to lower copper in serum as advocated by Hoogenraad. ${ }^{46}$

Capo et al determined the levels of $\mathrm{Cp}$ oxidative activity in the cerebrospinal liquor from $10 \mathrm{AD}$ patients and their controls. The results showed that $\mathrm{Cp}$ oxidative activity was significantly lower in the patients, whereas the copper concentration was the same in both groups. The results also showed that, normally, a relatively smaller part of the copper in the liquor is found bound to $\mathrm{Cp}$ than in serum. ${ }^{47}$ Although this finding is at variance with serum in this respect, the results indicate that the $\mathrm{Cp}$ oxidative activity is also lowered in this compartment in $\mathrm{AD}$ patients.

In contrast to iron, which is mostly transported bound to transferrin from the blood into the brain, ${ }^{20}$ copper most likely diffuses from blood to the brain in the ionized state. ${ }^{48}$ There is no lack of copper in the serum or cerebrospinal liquor of $\mathrm{AD}$ patients, ${ }^{15,47,49}$ thus, in the $\mathrm{AD}$ brain, the influx, or the efflux, of copper is seemingly compromised.

Clearly, the low amount of copper in the AD brain may lead to generally lesser synthesis in the brain of many copper enzymes besides ceruloplasmin. The superoxide dismutase 1 (SOD1), which scavenges the superoxide anion radical, is a copper enzyme with antioxidative function that is parallel to the activity of ceruloplasmin. However, judging from their activity in serum and red blood cells, respectively, separate processes of copper deprivation may prevail for $\mathrm{Cp}$ and SOD1. Thus, in the first AD study of the present authors, the activity of both enzymes was found significantly lowered in the patients, but independently. ${ }^{15}$ In the second AD study, ${ }^{16}$ which was performed 12 years later, determination of SOD1 was not included as the analytical kit used in the first study was no longer available.

In summary, iron is generally not increased in the $\mathrm{AD}$ brain. It accumulates in neuritic plaques and neurofibrillary tangles and can mediate tissue damage, resulting in axonal dysfunction and cell death. Cp oxidative activity in serum is lowered in AD. Defective incorporation of copper in $\mathrm{Cp}$, besides presumptive lack of enzyme copper in $\mathrm{AD}$ brain, could be an essential feature in AD.

\section{Conclusion}

A correlation exists between increased iron in the substantia nigra and lowered $\mathrm{Cp}$ concentration and activity in the serum of PD patients. Variations in the $\mathrm{Cp}$ gene have, as previously mentioned, been associated with increased iron in the substantia nigra and PD. ${ }^{25}$ It is known that PD often has an hereditary basis. In an Icelandic study from 2000, it was found that the risk of acquiring PD is much greater in persons closely related to PD patients than in unrelated persons; at the same time, the risk to patients' spouses was not increased. ${ }^{50}$ Accordingly, it should be one of the aims of future studies in this field to elucidate whether $\mathrm{Cp}$ gene variations or possible transcription defects are generally found in PD patients. Another intriguing and related research object is to delineate whether healthy persons with high amounts of iron in the substantia nigra are free of such deviations or defects.

The newly publicized findings that iron is generally not increased in the $\mathrm{AD}$ brain and that the brain is at the same time short of copper is of great importance. As there is no lack of copper in plasma in $\mathrm{AD}$, the signs and symptoms of copper deprivation in the disease would most likely be confined to the CNS. To the knowledge of the present authors, copper deprivation has not been much studied in humans. 
In this context, it should be mentioned that, in a 60 -yearold study of Icelandic ewes suffering from heavy copper shortage, the most conspicuous pathological defects in the brains of their lambs were lesions in neuronal myelin and demyelination..$^{51,52}$ Whether lesions in the iron-rich myelin sheath as envisaged by Texel et $\mathrm{al}^{33}$ might contribute to the pathological distribution of iron in the AD brain is at present an open question. At any rate, future studies on $\mathrm{Cp}$ in $\mathrm{AD}$ should also include research on other copper enzymes, which could further illuminate the pathogenesis of the disease. SOD1 was already mentioned above; another important copper enzyme is the multi-copper oxidase hephaestin. Hephaestin is a $\mathrm{Cp}$ homolog and is essential for the absorption of iron from the gastrointestinal tract, but it is also found with $\mathrm{Cp}$ in the cortical areas of the brain that are most affected in AD. ${ }^{33}$ Other proteins, like APP and the prion protein that are biologically connected with iron and copper and which may possess relevant enzymatic activities, should also be scrutinized in future studies on AD. ${ }^{35}$

In contrast to $\mathrm{PD}$, variations in the $\mathrm{Cp}$ gene have not been described in adult-onset AD. ${ }^{53}$ However, variations in the $\mathrm{Cp}$ gene or in the incorporation of copper in the $\mathrm{Cp}$ molecule might, if found, also be of importance in the etiology of AD.

In conclusion, defective $\mathrm{Cp}$ activity and concentration in serum are seemingly related to the occurrence of PD, and defective $\mathrm{Cp}$ activity in serum, along with defects in other copper enzymes, is possibly of importance in the etiology of AD.

\section{Acknowledgments}

The authors are indebted to Dr Kristín Björg Gudmundsdóttir for advice and discussions in preparing this text for publication.

\section{Disclosure}

The projects described in this work were financed by grants from scientific funds (the Scientific Fund of Helga and Sigurlidi Kristinsson and the Scientific Fund of the University of Iceland). The authors have not received any financial support for this submitted work or any honorarium from organizations or companies.

\section{References}

1. Roeser HP, Lee GR, Nacht S, Cartwright GE. The role of ceruloplasmin in iron metabolism. J Clin Invest. 1970;49:2408-2417.

2. Harris ZL, Durley AP, Man TK, Gitlin JD. Targeted gene disruption reveals an essential role for ceruloplasmin in cellular iron efflux. Proc Natl Acad Sci. 1999;96:10812-10817.

3. Jeong SY, David S. Glycosylphosphatidylinositol-anchored ceruloplasmin is required for iron efflux from cells in the central nervous system. $J$ Biol Chem. 2003;278:27144-27148.
4. Harris ZL, Takahashi Y, Miyajima H, Serizawa M, MacGillivray RT, Gitlin JD. Aceruloplasminemia: molecular characterization of this disorder of iron metabolism. Proc Natl Acad Sci. 1995;92:2539-2543.

5. Harris ZL, Klomp LW, Gitlin JD. Aceruloplasminemia: an inherited neurodegenerative disease with impairment of iron homeostasis. Am J Clin Nutr. 1998;67(Suppl):972S-977S.

6. Connor JR, Menzies SL, St Martin SM, Mufson EJ. A histochemical study of iron, transferrin, and ferritin in Alzheimer's diseased brains. J Neurosci Res. 1992;31:75-83.

7. Smith MA, Harris PL, Sayre LM, Perry G. Iron accumulation in Alzheimer's disease is a source of redox-generated free radicals. Proc Natl Acad Sci. 1997;94:9866-9868.

8. Ponka P. Hereditary causes of disturbed iron homeostasis in the central nervous system. Ann N Y Acad Sci. 2004;1012:267-281.

9. Jin L, Wang J, Zhao L, et al. Decreased serum ceruloplasmin levels characteristically aggravate nigral iron deposition in Parkinson's disease. Brain. 2011;134:50-58.

10. Martinez-Hernandez R, Montes S, Higuera-Calleja J, et al. Plasma ceruloplasmin ferroxidase activity correlates with the nigral sonographic area in Parkinson's disease patients: A pilot study. Neurochem Res. 2011;36:2111-2115.

11. Harris ZL, Morita H, Gitlin JD. The biology of human ceruloplasmin. In: Messerschmidt A, editor. Multi-Copper Oxidases. Singapore: World Scientific; 1997:285-305.

12. Torsdottir G, Gudmundsson G, Kristinsson J, Snaedal J, Johannesson T. Ceruloplasmin and superoxide dismutase (SOD1) in heterozygotes for Wilson's disease: A case control study. Neuropsychiatr Dis Treat. 2009;5:55-59.

13. Torsdottir G, Kristinsson J, Sveinbjörnsdottir S, Snaedal J, Johannesson T. Copper, ceruloplasmin, superoxide dismutase and iron parameters in Parkinson's disease. Pharmacol Toxicol. 1999;85:239-243.

14. Torsdottir G, Sveinbjörnsdottir S, Kristinsson J, Snaedal J, Johannesson T. Ceruloplasmin and superoxide dismutase (SOD1) in Parkinson's disease: A follow-up study. J Neurol Sci. 2006;241:53-58.

15. Snaedal J, Kristinsson J, Gunnarsdottir S, Olafsdottir A, Baldvinsson M, Johannesson T. Copper, ceruloplasmin and superoxide dismutase in patients with Alzheimer's disease. A case-control study. Dement Geriatr Cogn Disord. 1998;9:239-242.

16. Torsdottir G, Kristinsson J, Snaedal J, Johannesson T. Ceruloplasmin and iron proteins in the serum of patients with Alzheimer's disease. Dement Geriatr Cogn Disord Extra. 2011;1:366-371.

17. Zecca L, Youdim MB, Riederer P, Connor JR, Crichton RR. Iron, brain ageing and neurodegenerative disorders. Nat Rev Neurosci. 2004;5: $863-873$.

18. Altamura S, Muckenthaler MU. Iron toxicity in diseases of aging: Alzheimer's disease, Parkinson's disease and atherosclerosis. J Alzheimer's Dis. 2009;16:879-895.

19. Barnham KJ, Masters CL, Torsdottir G, Bush AI. Neurodegenerative diseases and oxidative stress. Nat Rev Drug Discov. 2004;3:205-214.

20. Johannesson T, Kristinsson J, Torsdottir G, Snaedal J. Serúlóplasmín og járn. Tengsl við Alzheimersjúkdóm og Parkinsonsjúkdóm. [Ceruloplasmin $(\mathrm{Cp})$ and iron in connection with Parkinson's disease (PD) and Alzheimer's disease (AD)]. Laeknabladid. 2012;98:531-537. Icelandic (with English summary).

21. Torsdottir G, Kristinsson J, Hreidarsson S, Snaedal J, Johannesson T. Copper, ceruloplasmin and superoxide dismutase (SOD1) in patients with Down's syndrome. Pharmacol Toxicol. 2001;89:320-325.

22. Torsdottir G, Kristinsson J, Snaedal J, et al. Case-control studies on ceruloplasmin and superoxide dismutase (SOD1) in neurodegenerative diseases: A short review. J Neurol Sci. 2010;299:51-54.

23. Arnal N, Cristalli DO, de Alaniz MJT, Marra CA. Clinical utility of copper, ceruloplasmin, and metallothionein plasma determinations in human neurodegenerative patients and their first-degree relatives. Brain Res. 2010;1319:118-130.

24. Berg D, Hochstrasser H, Schweitzer KJ, Riess O. Disturbance of iron metabolism in Parkinson's disease - ultrasonography as a biomarker. Neurotox Res. 2006;9:1-13. 
25. Hochstrasser H, Bauer P, Walter U, et al. Ceruloplasmin gene variations and substantia nigra hyperechogenicity in Parkinson's disease. Neurology. 2004;63:1912-1917.

26. Vassiliev V, Harris ZL, Zatta P. Ceruloplasmin in neurodegenerative diseases. Brain Res Rev. 2005;49:633-640.

27. Zecca L, Casella L, Albertini A, et al. Neuromelanin can protect against iron-mediated oxidative damage in system modeling iron overload of brain aging and Parkinson's disease. J Neurochem. 2008;106: 1866-1875.

28. Uversky VN. Neurotoxicant-induced animal models of Parkinson's disease: understanding the role of rotenone, maneb and paraquat in neurodegeneration. Cell Tissue Res. 2004;318:225-241.

29. Inden M, Kitamura Y, Abe M, Tamaki A, Takata K, Taniguchi T. Parkinsonian rotenone mouse model: Reevaluation of long-term administration of rotenone in C57BL/6 mice. Biol Pharm Bull. 2011;34: 92-96.

30. Hineno A, Kaneko K, Yoshida K, Ikeda S. Ceruloplasmin protects against rotenone-induced oxidative stress and neurotoxicity. Neurochem Res. 2011;36:2127-2135.

31. Blennow K. Alzheimers sjukdom - patofysiologi [Alzheimer's disease, pathophysiology]. Information från Läkemedelsverket. 2002;7/8:21-34. Swedish.

32. Yuraszeck TM, Neveu P, Rodriguez-Fernandez M, Robinson A, Kosik KS, Doyle III FJ. Vulnerabilities in the tau network and the role of ultrasensitive points in tau pathophysiology. PLoS Comput Biol. 2010; 6(11):e1000997.

33. Texel SJ, Xu X, Harris ZL. Ceruloplasmin in neurodegenerative diseases. Biochem Soc Trans. 2008;36:1277-1281.

34. Connor JR, Menzies SL. Cellular management of iron in the brain. J Neurol Sci. 1995;134(Suppl):33-44.

35. Gaggelli E, Kozlowski H, Valensin D, Valensin G. Copper homeostasis and neurodegenerative disorders (Alzheimer's, prion, and Parkinson's diseases and amyotrophic lateral sclerosis). Chem Rev. 2006;106: 1995-2044.

36. Smith MA, Zhu X, Tabaton M, et al. Increased iron and free radical generation in preclinical Alzheimer's disease and mild cognitive impairment. J Alzheimers Dis. 2010;19:363-372.

37. Nunomura A, Perry G, Aliev G, et al. Oxidative damage is the earliest event in Alzheimer's disease. J Neuropathol Exp Neurol. 2001;60: 759-767.

38. Schrag M, Mueller C, Oyoyo U, Smith MA, Kirsch WM. Iron, zinc and copper in the Alzheimer's disease brain: A quantitative meta-analysis. Some insight on the influence of citation bias on scientific opinion. Prog Neurobiol. 2011;94:296-306.
39. Quintana C, Bellefqih S, Laval JY, et al. Study of the localization of iron, ferritin, and hemosiderin in Alzheimer's disease hippocampus by analytical microscopy at the subcellular level. J Struct Biol. 2006;153: 42-54

40. Patel BN, Dunn RJ, Jeong SY, Zhu Q, Julien JP, David S. Ceruloplasmin regulates iron levels in the $\mathrm{CSN}$ and prevents free radical injury. J Neurosci. 2002;22(15):6578-6586.

41. Brewer GJ, Kanzer SH, Zimmerman EA, Celmins DF, Heckman SM, Dick R. Copper and ceruloplasmin abnormalities in Alzheimer's disease. Am J Alzheimers Dis Other Demen. 2010;25:490-497.

42. Sparks DL, Schreurs BG. Trace amounts of copper in water induce beta-amyoid plaques and learning deficits in a rabbit model of Alzheimer's disease. Proc Natl Acad Sci. 2003;100:11065-11069.

43. Squitti R, Pasqualetti P, Dal Forno G, et al. Excess of serum copper not related to ceruloplasmin in Alzheimer's disease. Neurology. 2005; 64:1040-1046

44. Squitti R, Bressi F, Pasqualetti P, et al. Longitudinal prognostic value of serum "free" copper in patients with Alzheimer's disease. Neurology. 2009;72:50-55.

45. Squitti R, Ghidoni R, Scrascia F, et al. Free copper distinguishes mild cognitive impairment subjects from healthy elderly individuals. J Alzheimers Dis. 2011;23:239-248.

46. Hoogenraad TU. Paradigm shift in treatment of Alzheimer's disease: zinc therapy now a conscientious choice for care of individual patients. Int J Alzheimers Dis. 2011:Article ID 492686.

47. Capo CR, Arciello M, Squitti R, et al. Features of ceruloplasmin in the cerebrospinal fluid of Alzheimer's disease patients. Biometals. 2008; $21: 367-372$.

48. Choi BS, Zheng W. Copper transport to the brain by the blood-brain barrier and blood-CSF barrier. Brain Res. 2009;1248:14-21.

49. Bucossi S, Ventriglia M, Panetta V, et al. Copper in Alzheimer's disease: A meta-analysis of serum, plasma, and cerebrospinal fluid studies. J Alzheimers Dis. 2011;24:175-185.

50. Sveinbjörnsdottir S, Hicks AA, Jonsson T, et al. Familial aggregation of Parkinson's disease in Iceland. N Engl J Med. 2000;343:1765-1770.

51. Palsson PA, Grimsson H. Demyelination in lambs from ewes which feed on seaweeds. Proc Soc Exper Biol Med. 1953;83:518-520.

52. Palsson PA, Grimsson H. Fjöruskjögur. Copper deficiency in lambs. Búnaðarrit. 1954;66:32-50. Icelandic.

53. Hollingworth $\mathrm{P}$, Harold $\mathrm{D}$, Sims R, et al. Common variants at $A B C A 7$, $M S 4 A 6 A / M S 4 A 4 E, E P H A 1, C D 33$ and $C D 2 A P$ are associated with Alzheimer's disease. Nat Genet. 2011;43:429-436.
Neuropsychiatric Disease and Treatment

\section{Publish your work in this journal}

Neuropsychiatric Disease and Treatment is an international, peerreviewed journal of clinical therapeutics and pharmacology focusing on concise rapid reporting of clinical or pre-clinical studies on a range of neuropsychiatric and neurological disorders. This journa is indexed on PubMed Central, the 'PsycINFO' database and CAS

\section{Dovepress}

The manuscript management system is completely online and includes a very quick and fair peer-review system, which is all easy to use. Visit http://www.dovepress.com/testimonials.php to read real quotes from published authors. 